\title{
Population Dynamics and Seasonal Incidence of Major Sucking Pests of Acid Lime, Citrus aurantifolia Swingle
}

\author{
B. Poovizhiraja ${ }^{1^{*}}$, C. Chinniah ${ }^{1}$, M. Murugan ${ }^{2}$, S. Irulandi ${ }^{3}$, \\ K. Eraivan Arutkani Aiyanathan ${ }^{4}$ and T.N. Balamohan ${ }^{5}$
}

${ }^{1}$ Department of Entomology, ${ }^{5}$ Department of Horticulture, Agricultural College and Research Institute, Madurai, TNAU, India

${ }^{2}$ Department of Entomology, TNAU, Coimbatore, India

${ }^{3}$ Department of Fruit crops, Horticultural College and Research Institute,

Periyakulam, TNAU, India

${ }^{4}$ Agricultural College and Research Institute, Killikulam, TNAU, India

*Corresponding author

\section{Keywords}

Acid lime, Seasonal incidence,

Aleurocanthus

woglumi,

Diaphorina citri

Article Info

Accepted:

04 April 2019

Available Online:

10 May 2019

\section{A B S T R A C T}

Seasonal incidence of blackfly, Aleurocanthus woglumi Ashby and citrus psyllids Diaphorina citri Kuwayama were studied on acid lime during September 2017 to August 2018. The influence of weather factors on population fluctuation of sucking pests in acid lime ecosystem was recorded at weekly intervals in fixed location. The study revealed that the occurrence of sucking pests was noticed throughout the study period $36^{\text {th }}\left(1^{\text {st }}\right.$ week of September) to $35^{\text {th }}$ ( $4^{\text {th }}$ week of August) standard weeks. The population of D. citri attained its first peak during $19^{\text {th }}$ standard week ( $1^{\text {st }}$ week of May) with 23.20 nymphs $/ 10 \mathrm{~cm}$ length of twig. The correlation studies (r) between weather parameters and D. citri population revealed that the maximum and minimum temperatures showed significant positive relationship ( $\mathrm{r}=0.63$ and 0.63 respectively), while relative humidity had significant negative relationship $(\mathrm{r}=-0.15)$ with $D$. citri, whereas rainfall exhibited non significant relationship $(\mathrm{r}=0.22)$ with $D$. citri. From the multiple linear regression analysis it is clear that all weather factors, had significant positively relationship. The population of $A$. woglumi attained its first peak during $23^{\text {rd }}$ standard week ( $1^{\text {st }}$ week of June) with 68.40 nymphs/leaf. During the present period observation, three peaks of A. woglumi were recorded, first peak coincided with $23^{\text {rd }}$ standard week $\left(1^{\text {st }}\right.$ week of June). The correlation studies ( $\mathrm{r}$ ) between weather parameters and A. woglumi population revealed that the maximum and minimum temperatures showed significant positive impact $(r=0.70$ and 0.89 respectively), while the relative humidity had significant negative impact $(r=-0.22)$ with $A$. woglumi, whereas rainfall exhibited non significant relationship $(r=0.17)$ with $A$. woglumi in acid lime ecosystem. From the multiple linear regression analysis it is clear that among the weather factors, maximum and minimum temperatures had significant positive relationship, while relative humidity exhibited significant negative association with $A$. woglumi in acid lime ecosystem. 


\section{Introduction}

Acid lime is mainly cultivated in Tamil Nadu, Andhra Pradesh, Maharashtra, Karnataka, Gujarat and Himachal Pradesh. It is widely grown in the southern region of Tamil Nadu also. Citrus is commercially grown throughout India and occupies a place of prime importance among the major fruits of India, which ranks third after mango and banana. India is one of the principal citrus growing countries in the world with an area of 10.55 lakh hectares with the production of 127.46 lakh tonnes of fruit annually with the productivity of 9.90 tonnes per hectare. In india, acid lime accounts for about 259,000 hectares with the production of 2,789,000 tonnes. In Tamil Nadu, acid lime occupies an area of 9,880 hectares with the production of 34,510 tonnes annually with the productivity of 3.49 tonnes per hectare (Anonymous, 2017). However, there is enormous production gap between potential and average yield. This yield gap is due to a number of cultural and environmental factors and also due to a wide range of insect pests. Citrus is one of the important fruit crops and is grown in more than 52 countries around the world.

In India, Citrus trees are reported to be damaged by more than 250 insect species during different stages of growth, from seedling in nursery till the plant exists (Butani, 1979). Loss due to pest infestation is range from 83-95 per cent (Randhava, 1974). The Citrus butterfly (Papilio spp.), citrus leaf miner (Phyllocnistis citrella Stainton), ash weevil (Myllocerus sp.), citrus leaf roller (Psorosticha zizyphi Stainton), citrus trunk borer, Agrilus sp., citrus blackfly (Aleurocanthus woglumi Ashby), citrus psylla (Diaphorina citri Kuwayama), citrus aphid (Toxoptera citricida Kirkaldy), citrus thrips (Scirtothrips citri Moult.), citrus whiteflies (Dialeurodes citri Ashmead), citrus red scale (Aonidiella aurantii), citrus mealybug
(Planococcus citri Risso) and citrus red mite (Panonychus citri McGregor) are the major pests that cause severe damage to acid lime. Among these, Citrus blackfly, A. woglumi Ashby is considered as agriculturally important insect in several countries due to economic loss that it causes (Batista et al., 2002). They suck the sap from the Phloem, thereby removing the nutrients and possibly debilitating the plants by injecting toxic saliva (Silva et al, 2011). Heavy infestations may cause fast deterioration of plants and yield reduction (Fasulo and Brooks, 1993). Fruit set is greatly reduced, losses caused by $A$. woglumi is up to 80 per cent and more (Eberling, 1954; Yamamoto et al., 2008).

Citrus psyllids (Diaphorina citri Kuwayama) also act as carriers of the bacteria Candidatus liberibacter asiaticus that cause fatal citrus disease, known as citrus greening (CGD) or Huanglongbing (Halbert and Manjunath, 2004; Mahmood et al., 2014). D. citri is a small sucking insect pest (2.7-3.3 mm long) with mottled brown body. Adults are very active and agile and move quickly for little disturbance.

These insect pests remain active from February to October with peak populations in spring and autumn seasons. However, spring population of $D$. citri is the most critical and damaging as this is the flowering and blooming period of citrus crop. Both adults and nymphs suck the sap from young foliage and leaves and tender shoots which in turn become yellowish with stunted growth and wither up. In case of severe attack, defoliation and premature fruit dropping occurs and these sucking insect pests can damage upto $50 \%$ to citrus crop if not controlled (Hall et al., 2013). The basic aim of this study was to assess the different prevailing abiotic factors which can act as the major determinants of pests populations on different citrus cultivars. 


\section{Materials and Methods}

To study the Impact of abiotic factors on the population of sucking pests in acid lime ecosystem with the incidence of sucking pests viz., citrus psyllids, citrus black fly were selected in hot spot area at Agricultural College and Research Institute, Madurai, during September 2017 to August 2018. Acid lime foliage of uniform age were selected randomly selected plants (10 Nos) per field were tagged properly/ block and the population of sucking pests were recorded at regular intervals (once in week). The weather parameters viz., Maximum and Minimum Temperatures $\left({ }^{\circ} \mathrm{C}\right)$, Relative humidity $(\%)$, Rain fall (mm) were also collected from automatic weather station installed at Agricultural college and research institute, Department of Central Farm, Madurai TNAU, for working out the correlation between weather parameters and population dynamics of sucking pests of acid lime in a given standard meteorological week. Correlation and regression analysis was also worked out with the weather parameters to understand the degree and extend of influence of these abiotic factors on the dynamics of pests populations on acid lime by SAS 9.2 and SPSS 17.0 statistical software package.

\section{Results and Discussion}

To understand the seasonal incidence of sucking pests in acid lime ecosystem, citrus field with uniform aged bushes were selected at Agricultural college and research institute, Madurai, during September 2017 to August 2018. The influence of weather factors on population fluctuation of sucking pests in acid lime ecosystem was recorded at weekly intervals in fixed location.

The study corroborated that the occurrence of sucking pests on acid lime (Table 1) found to occur throughout the study period $36^{\text {th }}\left(1^{\text {st }}\right.$ week of September $)$ to $35^{\text {th }}\left(4^{\text {th }}\right.$ week of August) standard week.

Initially the population of $D$. citri was fairly high followed by a gradual decrease from 14.1 to 0.7 nymphs $/ 10 \mathrm{~cm}$ twig length (Table 1 ). Then the population of $D$. citri gradually shoot up and progressed to reached its first peak during $19^{\text {th }}$ standard week $\left(1^{\text {st }}\right.$ week of May) with 23.20 nymphs $/ 10 \mathrm{~cm}$ twig length. Thereafter the population started increasing gradually coinciding with $4^{\text {th }}$ standard week ( $4^{\text {th }}$ week of January) followed by a declining trend from $20^{\text {th }}$ standard week $\left(2^{\text {nd }}\right.$ week of May) to $25^{\text {th }}$ standard week ( $3^{\text {rd }}$ week of June). Further, the D. citri population showed the increasing rate of multiplication gradually which reached its second peak during $35^{\text {th }}$ standard week $\left(4^{\text {th }}\right.$ week of August) recording 18.70 nymphs $/ 10 \mathrm{~cm}$ twig length. Subsequently there was a fluctuation in $D$. citri population from $4^{\text {th }}$ standard week $\left(4^{\text {th }}\right.$ week of January) to $34^{\text {th }}$ standard week $\left(4^{\text {th }}\right.$ week of August) and the minimum population could be observed during $4^{\text {th }}$ standard week ( $4^{\text {th }}$ week of January) with 0.6 nymph/ twig. The results also revealed that there was a lot of oscillation in D. citri population from $4^{\text {th }}$ January to $35^{\text {th }}$ August standard week because of erratic distribution of weather factors by which increasing and decreasing trend of $D$. citri population was observed (Figure 1). The present findings are in conformity with Teck et al., (2011) who found that D. citri population fluctuated throughout the year on honey mandarin but nymphs were generally higher during the rainy season i.e., from October to January than during the dry season which differ from the present finding due to the fact that only adults could be noticed for whole year but nymphal population was not found during December-January. The change in temperature coupled with increase of relative humidity reduced the nymphal population from October to December (39.25 to 0.34 nymphs $/ 10 \mathrm{~cm}$ twig). Zeb et al., 
(2011) noted that the highest (34 adults/leaf) population of $D$. citri on acid lime during May at Khanpur followed by Palai (5.5 adults/leaf) during June. Lowest population (0.7 adults per leaf was recorded in August year at Charbagh from Pakistan.

The correlation studies (r) between weather parameters and $D$. citri population revealed that (Table 2) the maximum and minimum temperatures exhibited significant positive relationship ( $\mathrm{r}=0.63$ and 0.63 respectively), while relative humidity alone had significantly negative relationship $(r=-0.15)$ with $D$. citri, where as rainfall exhibited non significant relationship $(\mathrm{r}=0.22)$ with $D$. citri in acid lime ecosystem. From the correlation analysis (Table 2), it is evident that an increase in maximum and a reduction in minimum temperatures by $1^{\circ} \mathrm{C}$, resulted in an increase of $D$. citri population by 1.91 and 0.96 per cent, nevertheless an increase in relative humidity by 1 per cent, there was a increase in $D$. citri population by 0.26 , while an increase in rainfall by $1 \mathrm{~mm}$, there was an increase in $D$. citri population by 0.30 per cent. Multiple linear regression analysis (Table 2) was also carried out by taking into account $D$. citri population as dependent and weather parameters as independent variables. The results revealed that the coefficient of determination was significantly high $\left(\mathrm{R}^{2}=\right.$ 0.505), which implies that these weather factors i.e., maximum temperature, minimum temperature, relative humidity and rainfall contributed directly towards the population buildup of $D$. citri in acid lime ecosystem to the extent of 50.50 per cent. From the multiple linear regression analysis it is clear that the all abiotic factors had significant positive relationship, with $D$. citri in acid lime ecosystem. These findings are coinciding with Patel (2007) who revealed a positive correlation between nymphal population of psyllid and minimum temperature, mean temperature and rain fall. Shivankar and Rao
(2005) reported that the pest was more active in spring and after monsoon flushes. The low incidence was observed during July (9.4 nymphs/ twig) and a high incidence was recorded during October (17.4 numphs/ twig). Patel and Patel (2006) observed the population of $D$. citri on kagzi lime was higher during March, June and October in North Gujarat. They also noted that minimum and maximum temperature had significantly positive influence on $D$. citri population on kagzi lime.

Initially the population of Aleurocanthus woglumi was high followed by gradual decrease from 35.70 to 4.90 nymphs/leaf. Then the population of $A$. woglumi gradually increased as they progressed and reached its first peak during $23^{\text {rd }}$ standard week ( $1^{\text {st }}$ week of June) with 68.40 nymphs/leaf (Table 1). The population started increasing gradually during $9^{\text {th }}$ standard week $\left(4^{\text {th }}\right.$ week of February). The sharp decline in A. woglumi population could be noticed from $24^{\text {th }}$ standard week ( $2^{\text {nd }}$ week of June) and Subsequently there was fluctuation in $A$. woglumi population from $9^{\text {th }}$ standard week $\left(4^{\text {th }}\right.$ week of February) to $35^{\text {th }}$ standard week ( $4^{\text {th }}$ week of August) and the minimum population could be observed during $2^{\text {nd }}$ standard week ( $2^{\text {nd }}$ week of January) with 4.90 nymphs/leaf (Figure 1). During the present period of study, three peaks were noticed the first peak during $23^{\text {rd }}$ standard week ( $1^{\text {st }}$ week of June). Similarly, Wilson et al., (2014) reported that A. woglumi was active throughout the year. The population of blackfly was the highest in March to April and number of overlapping generation was found continuously throughout the year. Medeiros et al., (2009) studied the populational dynamics of $A$. woglumi throughout the year. Correla (2011) observed that the seasonal incidence of $A$. woglumi was throughout the year and the peak activity was found during March to October. 
Table.1 Population dynamics of citrus psyllid, Diaphorina citri Kuwayama and citrus blackfly, Aleurocanthus woglumi Ashby in acid lime ecosystem (During September 2017- August 2018)

\begin{tabular}{|c|c|c|c|c|c|c|c|}
\hline $\begin{array}{c}\text { Standard } \\
\text { meteorological } \\
\text { weeks }\end{array}$ & $\begin{array}{c}\text { Date of } \\
\text { Observation }\end{array}$ & $\begin{array}{l}\text { Psyllid No. of } \\
\text { nymphs } / 10 \mathrm{~cm} \\
\text { length of twig }\end{array}$ & $\begin{array}{c}\text { Blackfly } \\
\text { No. of nymphs/ } \\
\text { leaf }\end{array}$ & $\begin{array}{c}\text { Standard } \\
\text { meteorological } \\
\text { weeks }\end{array}$ & $\begin{array}{c}\text { Date of } \\
\text { Observation }\end{array}$ & $\begin{array}{l}\text { Psyllid No. of } \\
\text { nymphs } / 10 \mathrm{~cm} \\
\text { length of twig }\end{array}$ & $\begin{array}{c}\text { Blackfly } \\
\text { No. of nymphs/ } \\
\text { leaf }\end{array}$ \\
\hline 05 September 2017 & 36 & 14.1 & 35.7 & 06 March 2018 & 10 & 3.9 & 11.7 \\
\hline 12 September 2017 & 37 & 11.4 & 34.4 & 13 March 2018 & 11 & 5.5 & 11.9 \\
\hline 19 September 2017 & 38 & 9.7 & 32.8 & 20 March 2018 & 12 & 8.1 & 22.8 \\
\hline 26 September 2017 & 39 & 9.3 & 31.9 & 27 March 2018 & 13 & 11.4 & 34.2 \\
\hline 03 October 2017 & 40 & 7.9 & 31.5 & 03 April 2018 & 14 & 14.5 & 34.8 \\
\hline 10 October 2017 & 41 & 6.2 & 30.6 & 10 April 2018 & 15 & 17.8 & 35.7 \\
\hline 17 October 2017 & 42 & 5.2 & 28.4 & 17 April 2018 & 16 & 20.3 & 37.4 \\
\hline 24 October 2017 & 43 & 2.4 & 28.1 & 24 April 2018 & 17 & 21.3 & 37.6 \\
\hline 31 October 2017 & 44 & 1.3 & 24.7 & 01 April 2018 & 18 & 22.5 & 48.7 \\
\hline 07 November 2017 & 45 & 1.1 & 24.2 & 08 May 2018 & 19 & 23.2 & 49.2 \\
\hline 14 November 2017 & 46 & 0.7 & 24.0 & 15 May 2018 & 20 & 18.3 & 51.4 \\
\hline 21 November 2017 & 47 & 0.0 & 23.8 & 22 May 2018 & 21 & 12.1 & 52.3 \\
\hline 28 November 2017 & 48 & 0.0 & 16.5 & 29 May 2018 & 22 & 9.6 & 52.6 \\
\hline 05 December 2017 & 49 & 0.0 & 13.5 & 05 June 2018 & 23 & 7.5 & 68.4 \\
\hline 12 December 2017 & 50 & 0.0 & 13.1 & 12 June 2018 & 24 & 4.1 & 62.2 \\
\hline 19 December 2017 & 51 & 0.0 & 11.4 & 19 June 2018 & 25 & 3.3 & 57.9 \\
\hline 26 December 2017 & 52 & 0.0 & 10.7 & 26 June 2018 & 26 & 3.9 & 49.1 \\
\hline 02 January 2018 & 1 & 0.0 & 8.4 & 03 July 2018 & 27 & 7.4 & 45.6 \\
\hline 09 January 2018 & 2 & 0.0 & 4.9 & 10 July 2018 & 28 & 10.6 & 44.2 \\
\hline 16January 2018 & 3 & 0.0 & 0.0 & 17 July 2018 & 29 & 14.2 & 46.2 \\
\hline 23 January2018 & 4 & 0.6 & 0.0 & 24 July 2018 & 30 & 15.3 & 41.1 \\
\hline 30 January2018 & 5 & 1.0 & 0.0 & 31 July 2018 & 31 & 12.4 & 38.3 \\
\hline 06 February 2018 & 6 & 1.2 & 0.0 & 07 August 2018 & 32 & 15 & 38.1 \\
\hline 13 February2018 & 7 & 2.2 & 0.0 & 14 August 2018 & 33 & 16.6 & 29.4 \\
\hline 20 February2018 & 8 & 2.4 & 0.0 & 21 August 2018 & 34 & 18.7 & 27.5 \\
\hline 27 February 2018 & 9 & 3.5 & 6.9 & 28 August 2018 & 35 & 18.7 & 27.2 \\
\hline
\end{tabular}


Table.2 Corelation and multiple linear regression models for weather parameters on Population dynamics of D. citri and A. woglumi in acid lime ecosystem (During September 2017- August 2018)

\begin{tabular}{|c|c|c|c|c|c|c|}
\hline \multirow[t]{3}{*}{ Populations } & \multicolumn{4}{|c|}{ Correlation Coefficient value } & \multirow[t]{2}{*}{ Multiple linear regression equation value } & \multirow{2}{*}{$\begin{array}{l}\text { Coefficient of } \\
\text { determination }\end{array}$} \\
\hline & $\begin{array}{c}\text { Maxi. } \\
\text { Temperature } \\
\left({ }^{0} \mathrm{C}\right)\end{array}$ & $\begin{array}{c}\text { Mini. } \\
\text { Temperature } \\
\left({ }^{0} \mathrm{C}\right)\end{array}$ & $\begin{array}{c}\text { Relative } \\
\text { Humidity } \\
(\%)\end{array}$ & $\begin{array}{c}\text { Rainfall } \\
\text { (mm) }\end{array}$ & & \\
\hline & (X1) & (X2) & (X3) & (X4) & $(\mathbf{Y})$ & $\left(\mathbf{R}^{2}\right)$ \\
\hline Diaphorina citri Kuwayama & $0.630 * *$ & $0.630 * *$ & -0.154 & 0.221 & $Y=-97.60+1.91 X_{1}+0.96 X_{2}+0.26 X_{3}+0.30 X_{4}$ & 0.505 \\
\hline $\begin{array}{l}\text { Aleurocanthus woglumi } \\
\text { Ashby }\end{array}$ & $0.700 * *$ & $0.890 * *$ & -0.222 & 0.176 & $Y=-124.42+0.25 X_{1}+8.52 X_{2}-0.76 X_{3}+0.00 X_{4}$ & 0.829 \\
\hline
\end{tabular}

**Significant at $1 \%$ Probability

*Significant at 5\% Probability

Fig.1 Population dynamics of citrus psyllid, Diaphorina citri Kuwayama and citrus blackfly, Aleurocanthus woglumi Ashby in acid lime ecosystem relation with weather parameters (During September 2017- August 2018)

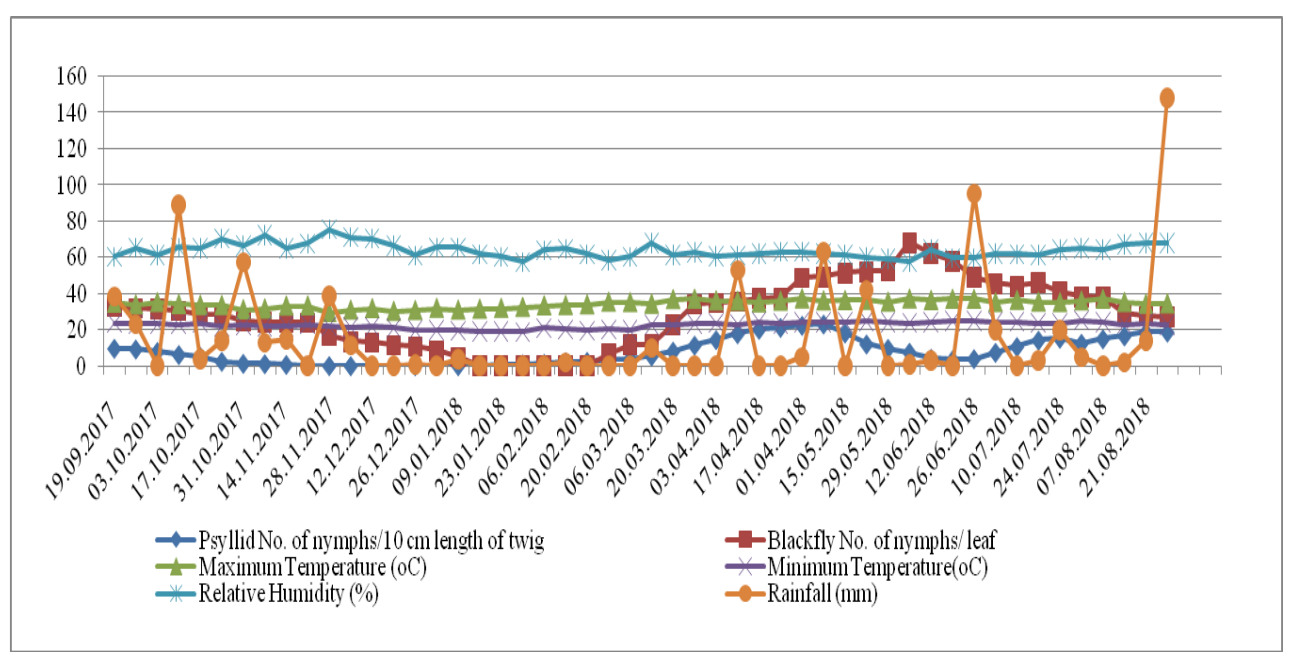


The correlation studies ( $r$ ) between weather parameters and $A$. woglumi population revealed that (Table 2) the maximum and minimum temperatures exhibited a significant positive influence $(\mathrm{r}=0.70$ and 0.89 respectively), while relative humidity had a significant negative relationship $(\mathrm{r}=-0.22)$ with $A$. woglumi, build up while rainfall exhibited non significant relationship ( $\mathrm{r}=$ 0.17 ) with $A$. woglumi in acid lime ecosystem. From the correlation analysis (Table 2), it is evident that an increase in maximum and minimum temperatures by $1{ }^{\circ} \mathrm{C}$ resulted in an increase of $A$. woglumi population by 0.25 and 8.52 per cent respectively, where as an increase in relative humidity by 1 per cent, there was a decline in A. woglumi population by 0.76 , respectively. Multiple linear regression analysis (Table 2) carried out by taking into account $A$. woglumi population as dependent variable and weather parameters as independent variable, revealed that the coefficient of determination was significantly high $\left(\mathrm{R}^{2}=0.829\right)$, which implies that these weather factors i.e., maximum temperature, minimum temperature, relative humidity and rainfall contributes directly towards the population build up of $A$. woglumi in acid lime ecosystem to an extent of 82.90 per cent. From the multiple linear regression analysis it is evident that among the weather factors, maximum and minimum temperatures had significant positive correlation, while relative humidity exhibited a significant negative association with $A$. woglumi in acid lime ecosystem. These finding fall in line with the report of Aruna et al., (2017), who also observed that the nymphal population had a highly significant positive correlation with the maximum temperature $(\mathrm{r}=0.43)$ and non significant positive correlation with the minimum temperature $(\mathrm{r}=0.43)$ and rainfall $(\mathrm{r}=0.43)$, whereas a highly significant negative correlation could be observed with relative humidity $(\mathrm{r}=0.43)$.

\section{References}

Anonymous, 2017. Horticultural Statistics at a Glance. Horticulture Statistics Division, Government of India. Pp. 15-427.

Aruna, J., Jagginavar, S. B., Karabhantanal, S. S., and Shalini, N., Huilgol. 2017. Seasonal incidence of citrus blackfly, Aleurocanthus woglumi ashby and its natural enemies on acid lime. J. Exp. Zool. India, 20: 1519-1523.

Batista, T.F.C., Rodrigues, R. C., Ohashi, O. S., Santos, M. M. de L. S., Oliveira, F. C. de., Soares, A. C. S., Lima, W. G., Castro, C. V. B. 2002. Identificação de fungos entomopatogênicos para controle da mosca negra dos citros Aleurocanthus woglumi Ashby (Hemiptera: Aleyrodidae). Praga quarentenária. Available at: http://www.ufpel.tche. br/sbfruti/ anais_xvii_cbf/fitopatologia/ 706.htm. [Review date: 26 March 2010].

Butani, D.K., 1979. Insect pests of citrus and their control. Pesticides 13(4): 15-21.

Correla, R.G., 2011. First record of occurance of Aleurocanthus Woglumi Ashby in Roraima. Revista Agro@mbiente., 5(3): 245-248.

Eberling, W., 1954. Subtropical Entomology (2nd edition), pp. 505- 508. Lithotype Process Co., San Francisco, USA.

Fasulo, T.R., and Brooks, R. F. 1993. Whitefly pests of Florida citrus. Gainesville: Department of Entomology and Nematology (ENY, 815). Available at: http://edis.ifas. ufl.edu. [Review date: 21 January 2010].

Halbert, S.E., and Manjunath, K. L. 2004. Asian citrus psyllids (Sternorryncha: Psyllidae) and greening disease of citrus: a literature review and assessment of risk in Florida. Florida Entomologist, 87: 330-53

Hall, D.G., Richardson, M. L., Ammar, E. D., Halbert, S. E. 2013. Asian citrus psyllid, Diaphorina citri (Hemiptera: Psyllidae), vector of citrus huanglongbing disease. Entomol. Exp. Appl., 146: 207223.

Hijam, S.D., and Sharma, D. R. 2014. Impact of abiotic factors on build-up of citrus psylla, Diaphorina citri Kuwayama 
population in Punjab, India. J. Appl. Natu. Sci. 6(2): pp.371-376.

Mahmood, R., Rehman, A., and Ahmad, M. 2014. Prospects of biological control of citrus insect pests in Pakistan. J. Agric. Res., 52(2): 229-244.

Medeiros, F.R., Raimunda, N. and Santos, D. 2009. Populational Dynamics of Citrus Blackfly, Aleurocanthus Woglumi Ashby (hemiptera: Aleyrodidae) in Citrus spp. in Sao Luis, Maranhao, Brazil, Bra. Mag. Fru. Cul., 31(4): 1016-1021.

Patel, C.C., 2007. Study on population dynamics, biology and management of citrus psylla, Diaphorina citri Kuwayama. M.Sc. (Agri.) thesis submitted to AAU, Anand.

Patel, P. S., and Patel, G. M. 2006. Population dynamics of important pest of citrus, Citrus aurantifolia Swingle. Ind. J. Ent., 68(3): 45

Randhava, G.S., 1974. Horticulture - Importance of pest control. Pesticides Annual., 8: 8587.

Silva, A.G., Farias, P. R. S., Boiça Junior, A. L., and Souza, B. H. S. 2011. Mosca-Negrados-Citros: Características Gerais, Bioecologia e Métodos de Controle dessa
Importante Praga Quarentenária da Citricultura Brasileira. Entomol Brasilis, 4: 85-91.

Teck, S.L.C., Fatimah, A., Beattie, A., Heng, R. K. J., and King, W. S. 2011. Seasonal Population Dynamics of the Asian Citrus Psyllid, Diaphorina citri Kuwayama in Sarawak. American Journal of Agricultural and Biological Sciences, 6(4): 527-535.

Wilson, J.J., Bergson, C., and Ribeiro. 2014. Impacts of climate change in the ecoclimatology of Aleurocanthus Woglumi Ashby (Hemiptera: Aleyrodidae) in the state of para., Rev. Bras. Meteoro. 29(1): pp.77-84.

Yamamoto, PT, Lopes, S., Bassanezi R B, Belasque Jr J and Sposito M B (2008) Citros: estrago à vista. Cultivar Hortaliças e Frutas 8: 22-24.

Zeb, Q., Khan, I., Inayatullah, M., and Hayat, Y. 2011. Population dynamics of Citrus whiteflies, aphids, citrus psylla, leafminer and their Biocontrol agents in Khyber Pakhtunkhwa. Sarh. J. Agri., 27(3): 451-457.

\section{How to cite this article:}

Poovizhiraja, B., C. Chinniah, M. Murugan, S. Irulandi, K. Eraivan Arutkani Aiyanathan and Balamohan, T.N. 2019. Population Dynamics and Seasonal Incidence of Major Sucking Pests of Acid Lime, Citrus aurantifolia Swingle. Int.J.Curr.Microbiol.App.Sci. 8(05): 386-393. doi: https://doi.org/10.20546/ijcmas.2019.805.046 